\title{
FPGA Based Vector Control of Induction Motor
}

\author{
G. Srinivas, S.Tarakalyani, P.V. Rama Krishna
}

\begin{abstract}
To get the desired response of the sensor less Vector controlled Induction Motor (SVC-IM) by the experimental setup, the controller implementation for the generation of the PWM signals is the key role. It is possible with the rapid growth of electronic industry such as high speed digital signal processors (DSPs) with micro controllers available in the present market. In the past DSP technologies were used to realize the several SVC-IM schemes, i.e. KF, PI, GA and PSO respectively. However, it creates issues related to the time delay and execution of the PWM signals, etc., as a results system becomes complex. Therefore a new approach is implemented to overcome the issues related to the execution time, namely Field Programmable Gate Array (FPGA) processors are suggested in the present market. Moreover the programming is done using very high speed hardware descriptive language (VHDL)
\end{abstract}

Keywords: FPGA, SVC, Induction Motor, MATLAB.

\section{INTRODUCTION}

To get the desired response of the SVC-IM by the experimental setup, the controller implementation for the generation of the PWM signals is a crucial role. It is possible with the rapid growth of the electronic industry, such as high-speed digital signal processors (DSPs) with microcontrollers available in the present market. In the past, DSP technologies were used to realize the several SVC-IM schemes, i.e., EKF, FLC, ANN, GA, and PSO, respectively. However, it creates issues related to the time delay and execution of the PWM signals; as a result, the system becomes complex. Therefore a new approach is implemented to overcome the issues related to the execution time, namely Field Programmable Gate Array (FPGA) processors are suggested in the present market. Moreover, the programming is done using very high-speed hardware descriptive language (VHDL). The FPGA is ideally suited for making high-performance processors with a capability for implementing highly parallel arithmetic architectures. The speed, size, and the number of inputs and outputs of a modern FPGA far exceed that of a microprocessor or DSP processor. At the last experimental setup for the SVC-IM with various control schemes such as the conventional Extended Kalman filter (EKF), PI-controller and evolutionary schemes like GA

Revised Manuscript Received on April, 022020.

* Correspondence Author

G. Srinivas, EECE Department, GITAM (Deemed to be University), Hyderabad, India. Email: gangishetti07@gmail.com

Dr. P.V. Rama Krishna*, EECE Department, GITAM (Deemed to be University), Hyderabad, India. Email: pvrk123@gmail.com

(C) The Authors. Published by Blue Eyes Intelligence Engineering and Sciences Publication (BEIESP). This is an open access article under the CC BY-NC-ND license (http://creativecommons.org/licenses/by-nc-nd/4.0/) and PSO was developed to verify with the simulation results. The performance characteristics of the conventional methods are thoroughly compared with known evolutionary control schemes like GA and PSO.

\section{HARDWARE IMPLEMENTATION}

\section{A. Block diagram of FPGA Based Controller for} SVC-IM (complete hardware configuration)

The complete circuit diagram of the project and the experimental setup is shown in Fig. 1. The three-phase 440V $50 \mathrm{~Hz}$ AC supply is fed to the three-phase diode bridge rectifier with a filter capacitor. DC is sensed by the current sensor (HE025T01). The dc output of the diode bridge rectifier is given to the three-phase PWM Voltage Source Inverter (VSI), which drives the three-phase squirrel cage induction motor. The three-phase A.C. Currents are sensed by three current sensors (HE025T01); these currents are inputs to the FPGA module.

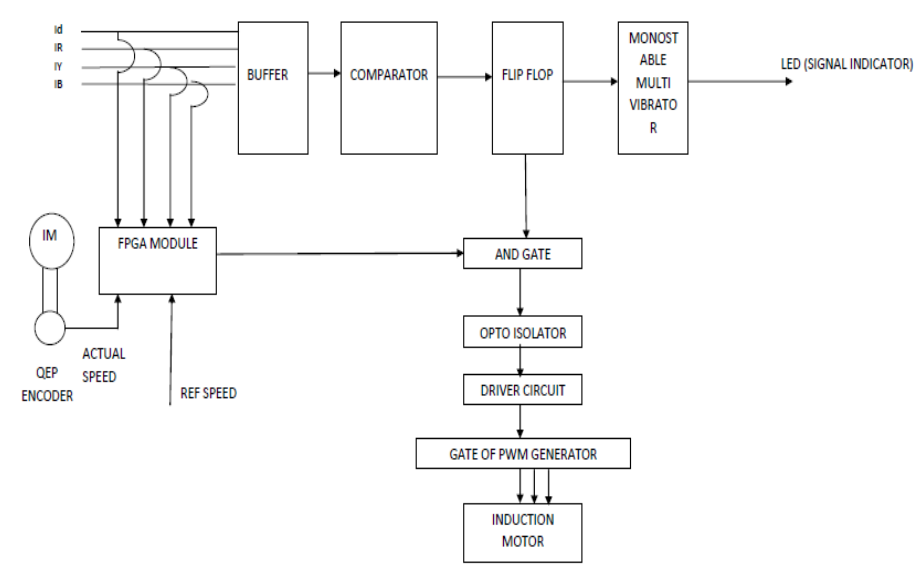

Fig. 1. The block diagram of the proposed FPGA based controller for SVCIM

\section{B. Power Circuit Unit}

The power circuit unit is shown in Fig. 2. It constitutes of a three-phase supply, diode bridge rectifier, DC sensor, AC sensor, and PWM VSI.

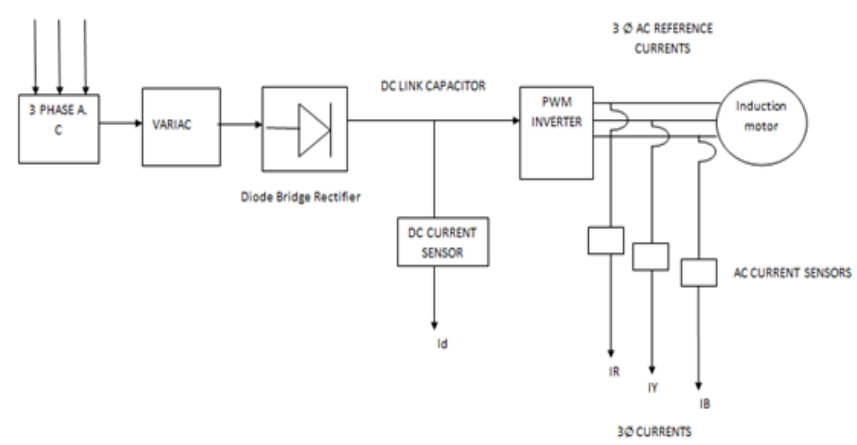

Fig. 2. The Power circuit unit

Published By:

Blue Eyes Intelligence Engineering

\& Sciences Publication

C) Convriaht: All riahts reserved.

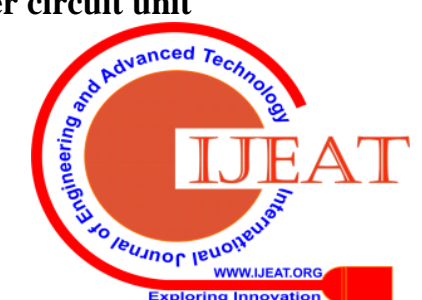




\section{FPGA Based Vector Control of Induction Motor}

\section{Speed Estimation Unit}

It consists of a QEP optical sensor, FPGA external hardware interrupt pin. In Indirect vector control scheme, the speed sensing is mandatory. The speed is measured by the simple arrangement of a QEP optical sensor. The sensor generates 512 pulses per rpm. By measuring the time of the pulse, we can measure the speed of the rotor in $\mathrm{rpm}$ or $\mathrm{rad} / \mathrm{s}$. The speed sensor output is given to the FPGA external hardware interrupt pin P3.2 (INT0) for measurement. The FPGA is programmed in such a way that it continuously measures the period of the pulses for measuring the speed.

\section{Signal Conditioner Unit}

The essential components include Buffer, comparator, flip flop, and monostable multivibrator. For protection, a signal conditioner is used. It consists of Buffer (TL084), Comparator (LM339), Flip Flop (4027), Monostable multivibrator (4098). The output currents of the current sensors are applied to buffer for smoothening, and the output of the buffer is applied to the comparator, which compares input DC and references current. If the input DC is well within the limits of the circuit, the comparator sends a signal to flip flop, and its output becomes high. The output of flip flop is sent as one of the input to AND gate (4081), the other input to AND gate is from the FPGA module, i.e., triggering pulses. When both inputs are high, the AND gate generates a high output, which transfers the triggering pulses to a driver circuit (IR2110) through opto isolators (6N137). (Used to isolate High voltage and Low voltage dc voltages) to the gate of Inverter. If it exceeds the limits, the comparator sends a signal to the monostable multivibrator, which in turn checks that no signal reaches the gate for firing pulse generation. Then the monostable multivibrator sends a signal to led to go red, indicating a warning. Then the input Three-phase supply controlled by a variac is reduced, which reduces input to the diode bridge rectifier and dc-link current and hence the output of an inverter. Power Circuit for accessories: It consists of dc power supplies for the buffer, comparator, opto isolator, flip flops, and multivibrator. The power supply unit also consists of 15-0-15V supply for buffer (consisting of IC 7915,bridge rectifier,15-0-15V transformer)and $0-15 \mathrm{~V}$ supply for comparator circuits (consisting of IC 7815, bridge rectifier and $0-15 \mathrm{~V}$ transformer), $0-5 \mathrm{~V}$ supply for opto isolator circuit, AND Gate, Flip flops and Monostable Multivibrator circuits(consisting of IC 7915, bridge rectifier,15-0-15V transformer)

\section{E. FPGA Module}

The FPGA module forms the heart of the controller which plays a vital role in the generation of gating signals for the PWM inverter. The outputs of the current sensors, speed encoders are connected to the inter phase board, and these signals reach the FPGA module through 34pin FRC (Flexible ribbon cable) cable to the FPGA input port. The FPGA unit senses these input signals and converts them to digital signals through A/D Convertors. The following sequence of events generates the switching signals.

1. by using the Up/down keys of the FPGA Module, the reference speed is set.

2. Reading actual speed from motor QEP Encoder and reference speed as set speed error is generated.

3. This speed error is applied to PI Controller, where Kp and Ki's values are loaded. The output of the PI Controller generates a torque component current (iq).
4. The flux of rated value is given to the motor, which generates flux component of current (id).

5. Generation of slip frequency $\omega$ sl from iq and id current components.

6. Generation of welectrical from wmechanical (from mechanical angle obtained from QEP encoder, multiplying by pair of poles)

7. Finding actual speed by adding $\omega$ mechanical and $\omega$ sl.

8. Generation of $\Theta$ by integrating $\omega \mathrm{m}$.

9. Formation of lookup tables for $\operatorname{Sin} \Theta$ and $\operatorname{Cos} \Theta$ values for unit vector generation.

10. Conversion from the d-q reference frame to $\boldsymbol{\alpha}-\boldsymbol{\beta}$ reference frame by park transformation and from $\boldsymbol{\alpha}-\boldsymbol{\beta}$ reference frame to a-b-c three-phase frame by Clarks Transformation.

11. Generation of switching signals for the PWM inverter gate.

\section{F. Inter phase board}

The FPGA pulses generated from the module are applied to the interphase board through 24 pin FRC Cable. The output of the interphase board is applied to the AND gate, which generates a signal of high when flip flop output goes high. The output of the AND gate is given to the optoisolator, which isolates the high voltage ground (15V) from low voltage ground (5V) through the driver circuit to the PWM Inverter gate.

\section{G. VHDL Coding Unit}

In this study, the Xilinx FPGA application board is taken as a basis for a real-time application. For analysis, an indirect field-oriented controlled induction machine driven by a Voltage Source Inverter (VSI) is analyzed by using the Matlab /Simulink model. The Xilinx FPGA chip generates the control signals for the VSI in the related model. But, the FPGA chip needs Very-high-speed Hardware Description Language (VHDL) codes to generate the control signals for the related controller. Usually, the Matlab Simulink Package does not provide an interface for the VHDL needed for the controller to be embedded in the FPGA chip. However, the Xilinx System Generator Tool provides such an interface, that is, a control algorithm developed by Xilinx System Generator Tool convenient to be used with traditional Simulink block sets can be translated to the VHDL codes needed for the controller for embedding in the FPGA chip.

The basics for VHDL Coding are as follows:

1. Library declaration

2. Input and Out variables declaration.

3. Local variable declaration.

4. Entity and architecture

5. Simulation and verification of logic.

6. Assigning PINs for output variables.

7. Generating program file i.e., .bit files.

8. Dumping the program to FPGA Module through emulator cable. The input power supply of $5 \mathrm{~V}$ is given through the adaptor whose input is $230 \mathrm{~V}$ A.C.

\section{H. Motor Unit}

A three-phase induction motor with a belt arrangement and mounting for QEP is used for analysis: The ratings of the motor considered are as follows:

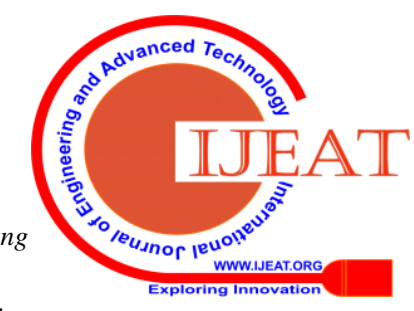


Table- I: The ratings of the motor

\begin{tabular}{|c|l|l|}
\hline Sino & Parameter & Rating \\
\hline 1 & Power & $1 \mathrm{H} . \mathrm{P}$. \\
\hline 2 & Voltage & $415 \mathrm{~V}$ \\
\hline 3 & Speed & $1430 \mathrm{Rpm}$ \\
\hline 4 & Frequency & $50 \mathrm{~Hz}$ \\
\hline 5 & No of Poles & 4 \\
\hline 6 & Current & $1.8 \mathrm{~A}$ \\
\hline
\end{tabular}

\section{EXPERIMENTAL AND SIMULATION ANALYSIS}

The analysis for speed, current, and torque for various loads for sensor less vector controlled induction motor implementing FPGA Module is as follows:

Case 1: Full load current of 1.8Aand speed of 1000rpm (Kalman filter controller)

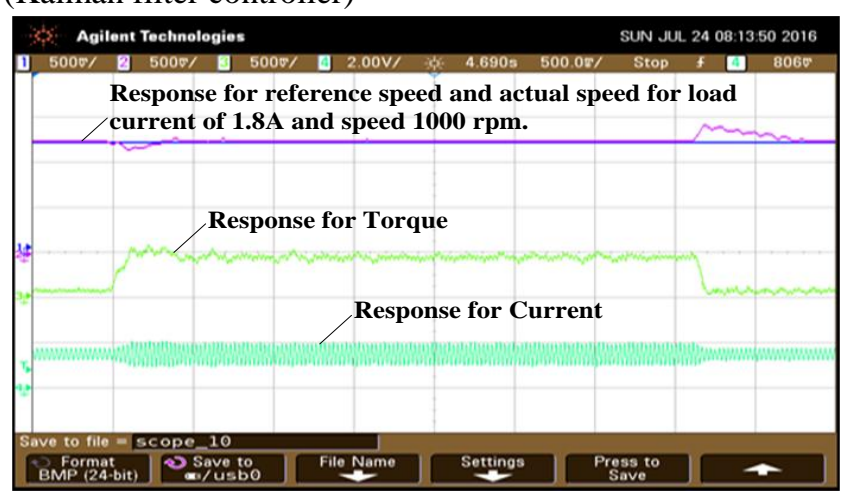

Fig. 3. Experimental results of actual speed, reference speed, torque, and current.

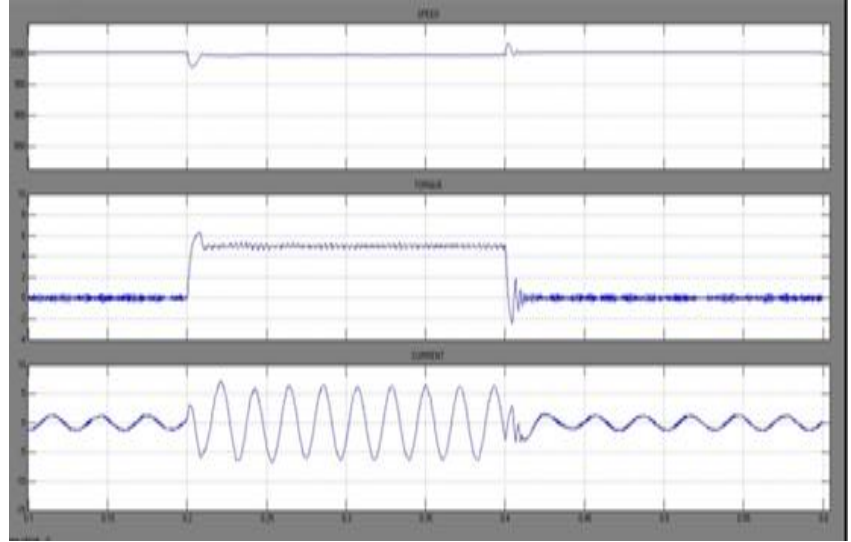

Fig. 4. Simulation results of actual speed, reference speed, torque, and current for Kalman Filter controller

The above analysis is done considering a Kalman filter controller for a full load current of $1.8 \mathrm{~A}$ and at a speed of $1000 \mathrm{rpm}$. The waveforms for actual speed, reference speed, current, and torque are shown in figure .12. When full load current is applied at 0.2 seconds, the speed drops to $950 \mathrm{rpm}$, and torque rises to $5.8 \mathrm{~N}-\mathrm{m}$ and load current increases to $2.75 \mathrm{~A}$.
Case 2: Full load current of $1.8 \mathrm{~A}$ and speed of $1000 \mathrm{rpm}$ (Conventional PI controller)

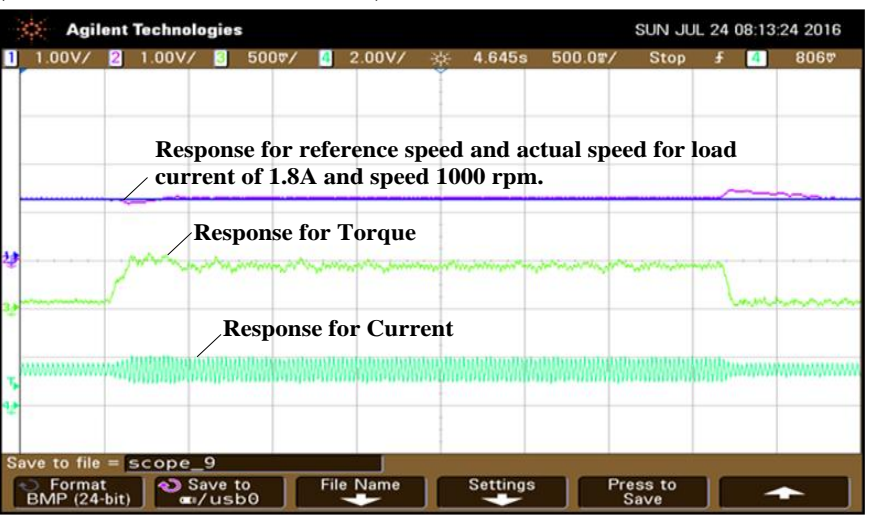

Fig. 5. Experimental results of actual speed, reference speed, torque, and current.

The analysis is done considering a Conventional PI controller for a full load current of 1.8A and at a speed of $1000 \mathrm{rpm}$. The waveforms for actual speed, reference speed, current, and torque are shown. When full load current is applied for 2 sec, the speed drops to $980 \mathrm{rpm}$, and torque rises to $5.65 \mathrm{Nm}$, and load current increases to 2.64A.

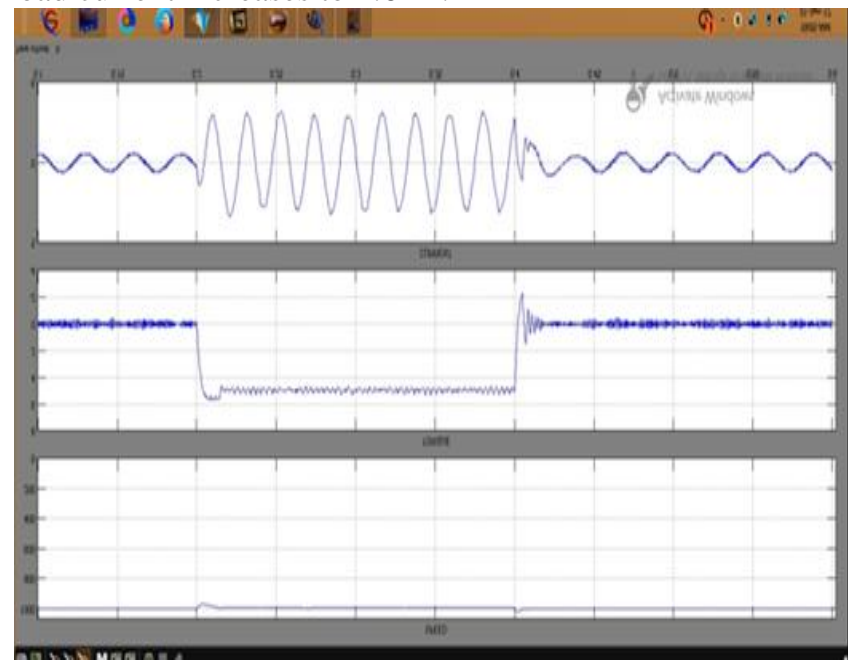

Fig. 6. Simulation results of actual speed, reference speed, torque, and current for the conventional PI controller.

Case 3: Full load current of $1.8 \mathrm{~A}$ and speed of $1000 \mathrm{rpm}$ (GA Tuned PI controller)

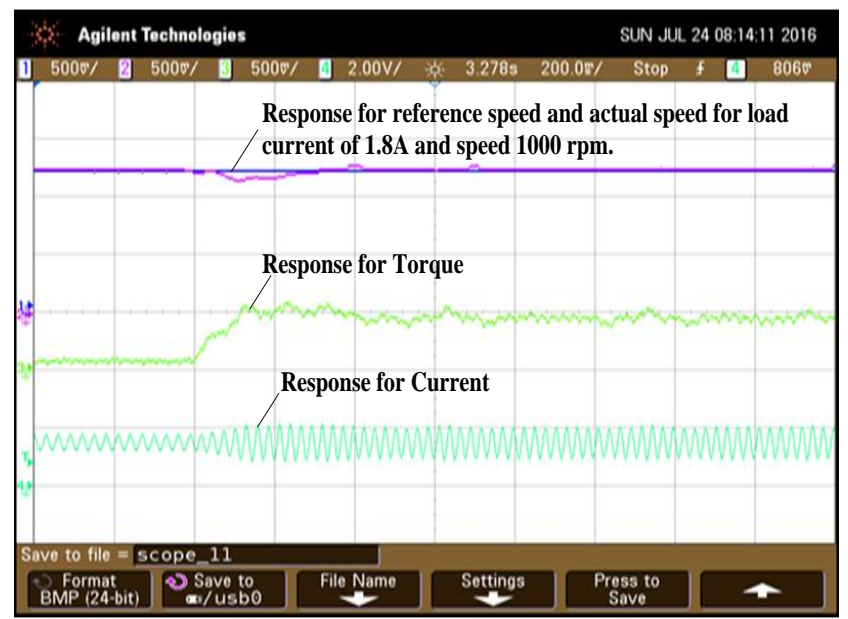

Fig. 7. Experimental results of actual speed, reference speed, torque, and current.

Published By:

Blue Eyes Intelligence Engineering

\& Sciences Publication

C Copvriaht: All riahts reserved.

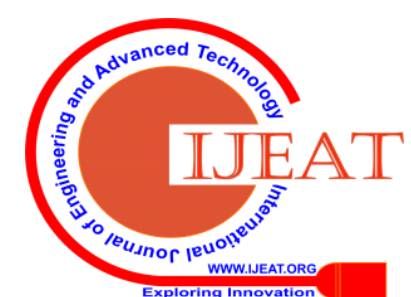




\section{FPGA Based Vector Control of Induction Motor}

The above analysis is done considering a GA Tuned PI controller for a full load current of $1.8 \mathrm{~A}$ at a speed of 1000 rpm. The waveforms for actual speed, reference speed, current, and torque are shown. When full load current is applied at $2 \mathrm{sec}$, the speed drops to $990 \mathrm{rpm}$, and torque rises to $5.2 \mathrm{Nm}$ and loads current increases to $2.5 \mathrm{~A}$.

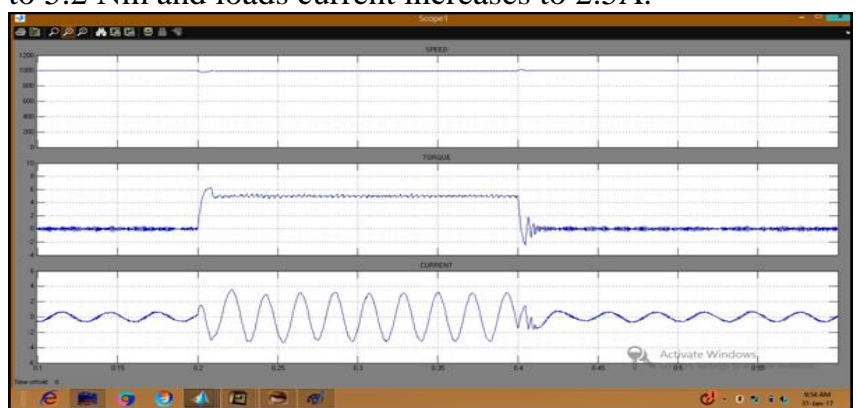

Fig. 8. Simulation results of actual speed, reference speed, torque and current

Case 4: Full load current of $1.8 \mathrm{~A}$ and speed of $1000 \mathrm{rpm}$ (PSO Tuned PI controller).

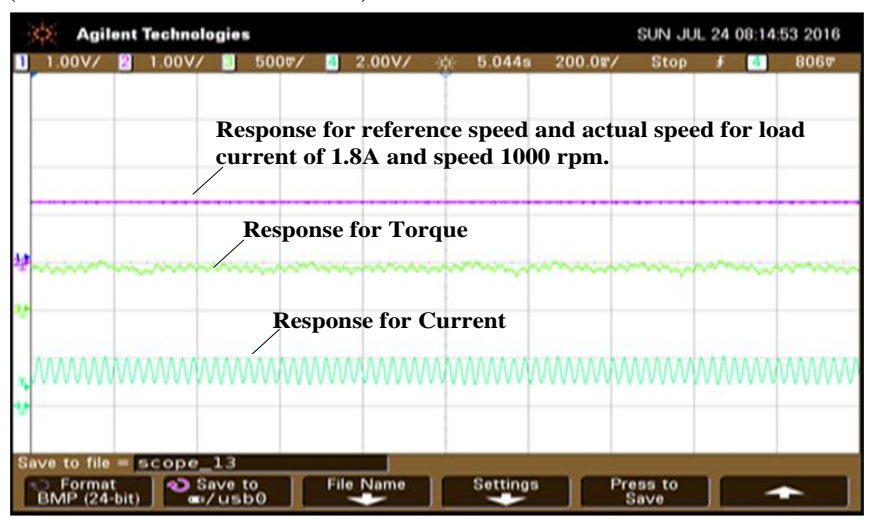

Fig. 9. Experimental results of actual speed, reference speed, torque, and current.

The above analysis is done considering a PSO Tuned PI controller for a full load current of $1.8 \mathrm{~A}$ at a speed of 1000 rpm. The waveforms for actual speed, reference speed, current, and torque are as shown. When full load current is applied for $2 \mathrm{sec}$, the speed drops to $995 \mathrm{rpm}$, and torque rises to $5.2 \mathrm{Nm}$ and load current increases to 2.2amps.

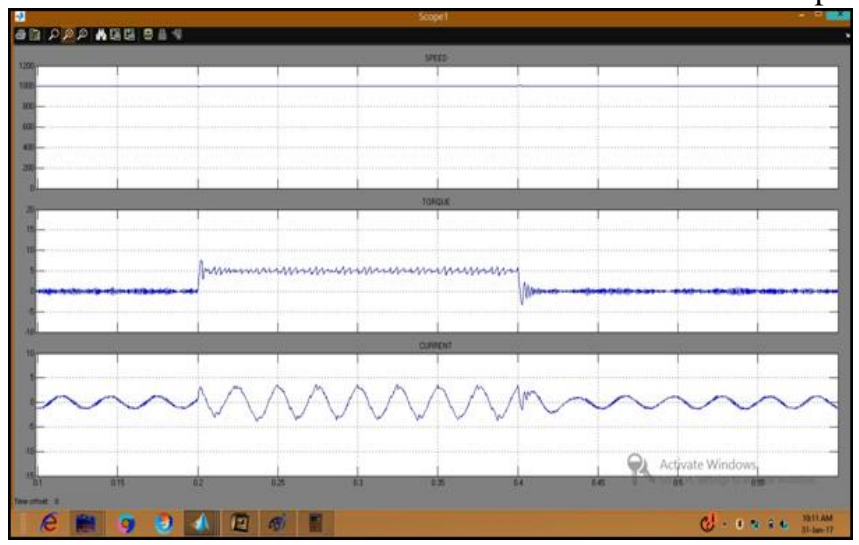

Fig. 10. Simulation results of actual speed, reference speed, torque, and current.

\section{COMPARISON OF SIMULATION AND HARDWARE RESULTS OF FPGA BASED CONTROLLER}

Case-1: The analysis is done at a full load current of $1.8 \mathrm{~A}$ and torque of $6 \mathrm{Nm}$ at a speed of $1000 \mathrm{rpm}$, as shown in Table- II. From the analysis at full load and speed of 1000rpm, the change in speed for Kalman filter controller is $5 \%$, the conventional PI controller is $2 \%$, GA tuned PI Controller is $1 \%$, and PSO tuned PI controller is $0.2 \%$. Similarly, the change in torque for the Kalman filter controller is $16 \%$, the conventional PI controller is 8\%, GA tuned PI Controller is $1 \%$, and PSO tuned PI controller is $0.4 \%$. The change in current for Kalman filter controller is $52.7 \%$, the conventional PI controller is $46.6 \%$, for GA tuned PI Controller is $38.8 \%$, and PSO tuned PI controller is $22.2 \%$.

Table- II: Analysis of the results for Case-1

\begin{tabular}{|l|l|l|l|l|}
\hline \multicolumn{1}{|c|}{ Parameter } & Kalman & $\begin{array}{c}\text { PI(conve } \\
\text { ntional) }\end{array}$ & $\begin{array}{c}\text { GA } \\
\text { tuned } \\
\text { PI }\end{array}$ & $\begin{array}{c}\text { PSO } \\
\text { tuned } \\
\text { PI }\end{array}$ \\
\hline $\begin{array}{l}\text { Speed(Rpm) } \\
\text { (simulation) }\end{array}$ & 950 & 980 & 990 & 996 \\
\hline $\begin{array}{l}\text { Speed } \\
\text { (Experimental) }\end{array}$ & 955 & 976 & 984 & 995 \\
\hline $\begin{array}{l}\text { Torque(N-m) } \\
\text { (simulation) }\end{array}$ & 5.8 & 5.65 & 5.4 & 5.2 \\
\hline $\begin{array}{l}\text { Torque } \\
\text { (Experimental) }\end{array}$ & 5.7 & 5.6 & 5.4 & 5.2 \\
\hline $\begin{array}{l}\text { Current(Amps) } \\
\text { (simulation) }\end{array}$ & 2.75 & 2.64 & 2.5 & 2.2 \\
\hline $\begin{array}{l}\text { Current } \\
\text { (Experimental) }\end{array}$ & 2.74 & 2.65 & 2.5 & 2.1 \\
\hline
\end{tabular}

Case-2: The analysis is done at 3/4 full load current, i.e., 1.35 A and torque of $6 \mathrm{~N}-\mathrm{m}$ at a speed of $1000 \mathrm{rpm}$, as shown in Table-III. From the above analysis at full load and speed of $1000 \mathrm{rpm}$ the change in speed for kalman filter controller is $4 \%$, conventional PI controller is $2 \%$, GA tuned PI Controller is $1 \%$ and PSO tuned PI controller is $0.2 \%$.The change in torque for Kalman filter controller is $16 \%$, conventional PI controller is $15 \%$, GA tuned PI Controller is $4 \%$ and PSO tuned PI controller is $1 \%$. The change in current for Kalman filter controller is $77.7 \%$, conventional PI controller is $62.8 \%$, GA tuned PI Controller is $60 \%$ and PSO tuned PI controller is $55.5 \%$.

Table- III: Analysis of the results for Case-2

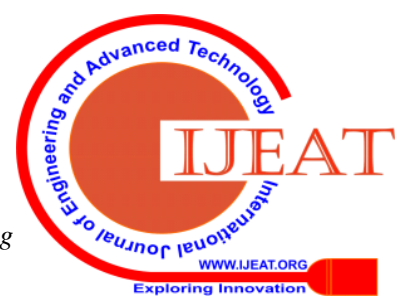




\begin{tabular}{|l|l|l|l|l|}
\hline Parameter & Kalman & PI(conventional) & $\begin{array}{l}\text { GA } \\
\text { tuned } \\
\text { PI }\end{array}$ & $\begin{array}{l}\text { PSO } \\
\text { tuned } \\
\text { PI }\end{array}$ \\
\hline $\begin{array}{l}\text { Speed(Rpm) } \\
\text { (simulation) }\end{array}$ & 960 & 980 & 990 & 995 \\
\hline $\begin{array}{l}\text { Speed } \\
\text { (Experimental) }\end{array}$ & 965 & 975 & 980 & 980 \\
\hline $\begin{array}{l}\text { Torque(N-m) } \\
\text { (simulation) }\end{array}$ & 5.8 & 5.75 & 5.2 & 5.05 \\
\hline $\begin{array}{l}\text { Torque } \\
\text { (Experimental) }\end{array}$ & 5.6 & 5.70 & 5.3 & 5.04 \\
\hline $\begin{array}{l}\text { Current(Amps) } \\
\text { (simulation) }\end{array}$ & 2.4 & 2.2 & 2.16 & 2.1 \\
\hline $\begin{array}{l}\text { Current } \\
\text { (Experimental) }\end{array}$ & 2.5 & 2.2 & 2.18 & 2.2 \\
\hline
\end{tabular}

Table- V: Analysis of the results for Case-2

\section{COMPARISON OF RESULTS}

Table- IV: Analysis of the results for Case-1

\begin{tabular}{|l|l|l|l|l|}
\hline Parameter & Kalman & $\begin{array}{l}\text { PI(conve } \\
\text { ntional) }\end{array}$ & $\begin{array}{l}\text { GA } \\
\text { tuned } \\
\text { PI }\end{array}$ & $\begin{array}{l}\text { PSO } \\
\text { tuned } \\
\text { PI }\end{array}$ \\
\hline $\begin{array}{l}\text { Speed(Rpm) } \\
\text { (simulation) }\end{array}$ & 950 & 980 & 990 & 996 \\
\hline $\begin{array}{l}\text { Speed } \\
\text { (Experimental) }\end{array}$ & 955 & 976 & 984 & 995 \\
\hline $\begin{array}{l}\text { Torque(N-m) } \\
\text { (simulation) }\end{array}$ & 5.8 & 5.65 & 5.4 & 5.2 \\
\hline $\begin{array}{l}\text { Torque } \\
\text { (Experimental) }\end{array}$ & 5.7 & 5.6 & 5.4 & 5.2 \\
\hline $\begin{array}{l}\text { Current(Amps) } \\
\text { (simulation) }\end{array}$ & 2.75 & 2.64 & 2.5 & 2.2 \\
\hline $\begin{array}{l}\text { Current } \\
\text { (Experimental) }\end{array}$ & 2.74 & 2.65 & 2.5 & 2.1 \\
\hline
\end{tabular}

Case-1: The analysis is done at a full load current of 1.8A and torque of $6 \mathrm{Nm}$ at a speed of 1000rpm, as shown in Table-IV. From the analysis at full load and speed of 1000rpm, the change in speed for Kalman filter controller is $5 \%$, the conventional PI controller is $2 \%$, GA tuned PI Controller is $1 \%$, and PSO tuned PI controller is $0.2 \%$. Similarly, the change in torque for the Kalman filter controller is $16 \%$, the conventional PI controller is $8 \%$, GA tuned PI Controller is $1 \%$, and PSO tuned PI controller is $0.4 \%$. The change in current for Kalman filter controller is $52.7 \%$, the conventional PI controller is $46.6 \%$, for GA tuned PI Controller is $38.8 \%$, and PSO tuned PI controller is $22.2 \%$. Case-2: The analysis is done at 3/4 full load current, i.e., $1.35 \mathrm{~A}$ and torque of $6 \mathrm{~N}-\mathrm{m}$ at a speed of 1000rpm, as shown in Table-V. From the above analysis at full load and speed of 1000rpm the change in speed for kalman filter controller is $4 \%$, conventional PI controller is $2 \%$, GA tuned PI Controller is $1 \%$ and PSO tuned PI controller is $0.2 \%$. The change in torque for kalman filter controller is $16 \%$, conventional PI controller is $15 \%$, GA tuned PI Controller is $4 \%$ and PSO tuned PI controller is $1 \%$. The change in current for kalman filter controller is $77.7 \%$, conventional PI controller is 62.8\%, GA tuned PI Controller is $60 \%$ and PSO tuned PI controller is $55.5 \%$.

\begin{tabular}{|l|l|l|l|l|}
\hline Parameter & Kalman & $\begin{array}{l}\text { PI(conve } \\
\text { ntional) }\end{array}$ & $\begin{array}{l}\text { GA } \\
\text { tuned } \\
\text { PI }\end{array}$ & $\begin{array}{l}\text { PSO } \\
\text { tuned } \\
\text { PI }\end{array}$ \\
\hline $\begin{array}{l}\text { Speed(Rpm) } \\
\text { (simulation) }\end{array}$ & 960 & 980 & 990 & 995 \\
\hline $\begin{array}{l}\text { Speed } \\
\text { (Experimental) }\end{array}$ & 965 & 975 & 980 & 980 \\
\hline $\begin{array}{l}\text { Torque(N-m) } \\
\text { (simulation) }\end{array}$ & 5.8 & 5.75 & 5.2 & 5.05 \\
\hline $\begin{array}{l}\text { Torque } \\
\text { (Experimental) }\end{array}$ & 5.6 & 5.70 & 5.3 & 5.04 \\
\hline $\begin{array}{l}\text { Current(Amps) } \\
\text { (simulation) }\end{array}$ & 2.4 & 2.2 & 2.16 & 2.1 \\
\hline $\begin{array}{l}\text { Current } \\
\text { (Experimental) }\end{array}$ & 2.5 & 2.2 & 2.18 & 2.2 \\
\hline
\end{tabular}

\section{EXPERIMENTAL HARDWARE SETUP}

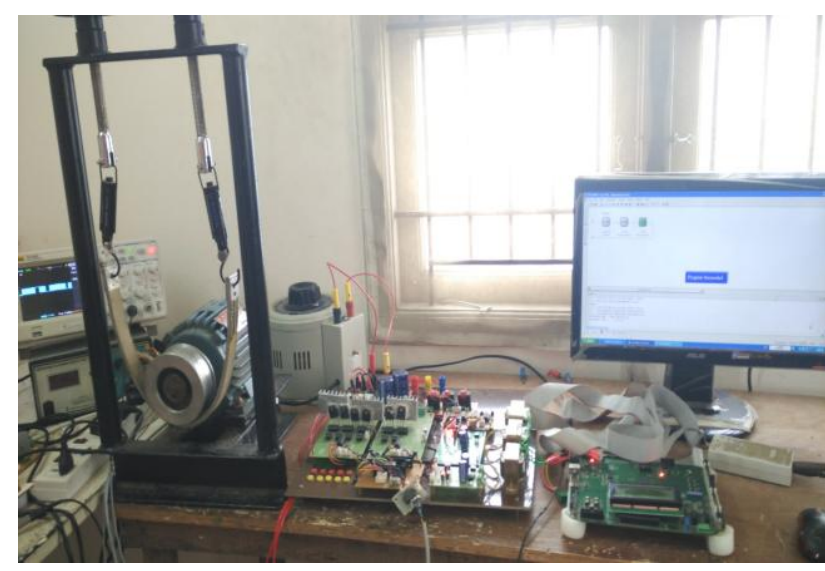

Fig. 11. Experimental setup for hardware

\section{CONCLUSION}

The desired response of the sensor less Vector controlled Induction Motor (SVC-IM) is obtained by an experimental setup. The controller implementation for the generation of the PWM signals is the key role. High speed digital signal processors (DSPs) with micro controllers available in the present market are made use of and compared to the past DSP technologies which were used to realize the several SVC-IM schemes, i.e. KF, PI, GA and PSO respectively. However, it creates issues related to the time delay and execution of the PWM signals, etc., as a result system becomes complex. The issues are addressed by a new approach and are implemented to overcome the issues related to the execution time, namely Field Programmable Gate Array (FPGA) processors are suggested in the present market. Moreover the programming is done using very high speed hardware descriptive language (VHDL).

\section{ACKNOWLEDGMENT}

We are very thankful to (GITAM Deemed to be university) management and supporting staff members who has helped directly or in directly in publishing this paper, it wouldn't be possible without their constant support and encouragement.

Published By:

Blue Eyes Intelligence Engineering

\& Sciences Publication

(C) Convriaht: All riahts reserved.

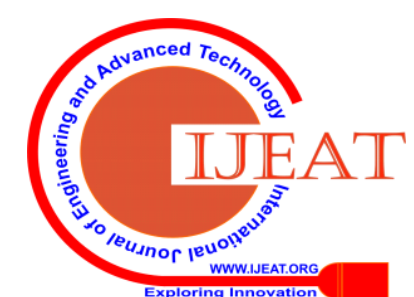




\section{REFERENCES}

1. K. Tazi, E. Monmasson, "Single-Chip DSP Based Speed Control of Two AC-Machine," Speedam, Sorrento (Italy), 1998, pp. 33 -38.

2. T. Takahashi, J. Goetz "Implementation of Complete AC Servo Control in a Low-Cost FPGA and Subsequent ASSP Conversion," IEEE, 2004. Engineering 1 (2), Me dwell Journals, 2007 pp. 225-259.

3. G.G. Parma, V. Dinavahi, "Real-Time Digital Hardware Simulation of Power Electronics and Drives," IEEE Transactions on power delivery,2007, Vol. 22, No. 2,pp.1235-1246.

4. M.Cristea, A.Aounis, M.Macromick, P.Urwin, L.Haydock, "Induction Motor Drive System Modelled in VHDL" Proceedings VHDL International Users Forum Fall Workshop IEEE August 2002, ISBN 0-7695-0890-1.

5. B. Hariram, N. S. Marimuthu, "A VHDL Library of Modules for Vector Control of IM," International Journal of Electrical and Power.

6. G. Mailloux, S. Simard, R. Beguenane, "Implementation of Division and Square Root Using XSG for FPGA Based Vector Control Drives," International Journal of Electrical and Power Engineering 1 (5)

7. S. K. Shoo, G. T. R. Das, V. Subramanian "Implementation and Simulation of Direct Torque Control Scheme with the Use of FPGA Circuit," ARPN Journal of Engineering and Applied Sciences, Vol. 3, No. 2, ISSN: 1819-6608, 2008.

8. Ozkan AKIN, Irfanalan "The use of FPGA in field-oriented control of an induction machine "Turk J Elec Eng\& Comp Sci, Vol.18, No.6, 2010.

9. J. Vásárhelyi, M. Imecs, CS. Szabó, I. Incze, T. Adám" FPGA Implementation of the Reconfigurable Control System for AC Drives Fed by Tandem Converter, Romania, CD-ROM, Vol-2, 2011, pp.475-448.

10. R.Rajendran, Senior Member IACSIT and Dr.N.Devarajan "FPGA Based Implementation of Space Vector Modulated Direct Torque Control For IM Drive" International Journal of Computer and Electrical Engineering, Vol. 2, No. 3, June 2010,pp.1793-8163.

\section{AUTHORS PROFILE}

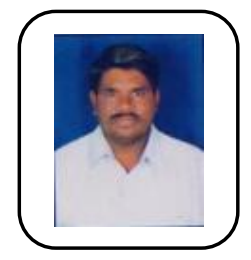

G. Srinivas Obtained B. Tech from J.N.T.U. Hyderabad in the year 1997 and M. Tech in Power electronics from J.N.T.U. Hyderabad in the year 2002 and Perusing PhD from J.N.T.U. H. Hyderabad. Presently working as Assistant Professor in G.I.T.A.M. University Hyderabad campus. His areas of interest include Power electronics and drives and optimization techniques.

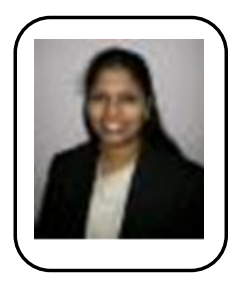

Dr.S.Tarakalyani received the B.Eng.degree in Electrical and Electronics from Osmania University, Hyderabad in 1995. She received the Ph.D. degree from Jawaharlal Nehru technological university (JNTU) Hyderabad in 2008. She is currently a Professor and Controller of Examinations at J.N.T.U.H. Her research interests include Facts Controllers, Power electronics industrial drives and Energy systems..

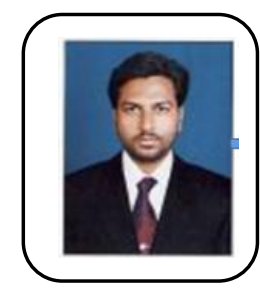

Dr. P.V. Rama Krishna obtained Osmania University, Hyderabad. M. Tech from IIT Roorkee, $\mathrm{PhD}$ from JNTU Hyderabad. He has total 10 years of teaching and industrial experience. Presently he is working as Assistant Professor in GITAM (Deemed to be University). His areas of interest are Power Systems operation and control, application of artificial intelligence techniques to power systems.

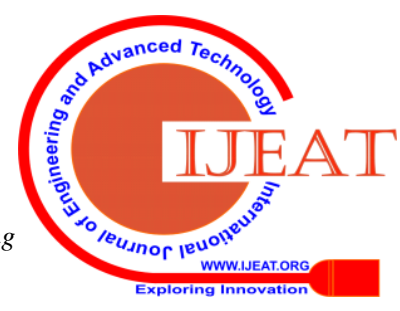

